\title{
Mechanized Non-Destructive Testing of Steel Billets
}

\author{
a summary of a paper by D. A. Hayes
}

Mechanized non-destructive testing methods for surface and internal defects in steel must meet several requirements:

1) A minimum of additional labor;

2) A minimum of testing time;

3) The capability of scanning $100 \%$ of the material; and

4) The production of information which can be used to make the optimum disposition of the product, and which is suitable for study toward the end of optimizing previous processing with respect to quality.

Progress toward these goals has been largely attained by installations which combine automatic material handling with two of the fundamental principles of physical science-magnetism for the detection of surface defects, and sound for the detection of internal defects.

Typical of such developments for the in-process detection of defects is one of the magnetic particle inspection units, for billets intended for re-rolling into bar products, installed at U. S. Steel's Gary Works, and the method designed to adapt this equipment to include ultrasonic inspection.

Of interest also is the prototype of an ultrasonic inspection station for finished plate product built and operated at Gary Works. In addition, Gary sheet and tin works makes use of Continuous Non-Destructive Magnetic Testing of Steel Strip, which is to be described in a paper scheduled for the Operating Metallurgy Conference in Pittsburgh.

The surface inspection of certain critical quality classifications of billet product is performed at Gary Works by magnetic particle inspection. Most of the billet surface defects are seams-defects of varying depth occurring in a lengthwise direction.

To detect such defects, a unit employing the principle of circular magnetization is used.

In actual practice, the billet is sprayed with a suspension of iron powder to which a fluorescent material has been added. It is then placed between two electrical contacts, and a high-amperage low-voltage current is passed lengthwise through the billet. The current creates a circular magnetic field. Polarity will then occur at any longitudinal de-

D. A. HAYES is chief metallurgist at U.S. Steel Corp.'s Gary Works. The original paper was prepared for the Chicago Technical Meeting of the American Iron and Steel Institute, October 1965. fect and hold the iron powder. Its fluorescence under black light will indicate the defect. Inspection can be performed to a range of seam depth criteria by varying the amperage of the electrical current.

The equipment performing this function can process billets ranging from $13 / 4$ to 4 in. $^{2}$ and from 15 to $40 \mathrm{ft}$ in length, at a rate of 100 per hour.

The billets are positioned by a ferris wheel arrangement on a rotating shaft, sprayed with a magnetic powder suspension, magnetized, inspected, and marked. After the completion of inspection, the wheel is rotated $180^{\circ}$. This movement drops the billet at the bottom completely inspected on four sides to the run-out table.

The principal advantages from the use of magnetic particle inspection equipment at this stage of processing are to obtain the highest possible percent of billets requiring no conditioning and the best bar quality possible when the billets are converted into finished product.

Ability to control the surface quality level of material intended for processing through the magnetic particle inspection unit is the most critical item contributing to the productivity of the machine and potential savings in conditioning. Using the percent of billet which meets the seam depth standard (those requiring no conditioning) as a barometer of surface quality, several techniques of statistical mathematics have been applied to determine what combinations of factors in steelmaking and primary conversion will yield the maximum percent of billets requiring no conditioning. Data representing the quality level of the product and factors related to its prior processing have been experimentally fed into an off-line computer. By a mathematical technique known as step-wise discriminant analysis, it has been possible to screen out those processing factors which affect the level of surface quality and to show their combined effect on surface quality in the form of a process index.

Magnetic particle inspection data has proved a considerably better measure of surface quality than other forms used before and can be more readily and accurately correlated with processing data. The combination of this new source of knowledge, existing process data, and the off-line computer make it possible to analyze surface-quality problems quickly and make the necessary process changes to improve quality.

During the early part of 1965, a program was inaugurated to develop a mechanized ultrasonic billet testing device that could be installed on the magnetic particle inspection line. The adaptation of this line to ultrasonic testing would then make it possible to give billets a combination surface and internal quality test with one handling operation.

The method developed utilized a wheel-type search unit. This unit (Fig. 1) operates on the immersion principle where waves of high-frequency sound are projected through a liquid path into the test material. The transducer or search unit crystal is mounted on the axle of a liquid-filled flexible wheel and is held in a fixed position relative to the test surface while the wheel rotates freely. Material may be moved under a fixed wheel, or the assembly may be moved over the surface of the material.

Two wheel search units are used on the Gary Works billet tester. The wheels are mounted at right angles to each other in order to test the billet through two planes. They (Continued on page 1418) 


\section{Testing}

(Continued from page 1280)

both contain 1-in. ${ }^{2}$, 2.25-Mc barium titanate transducers. The wheels are attached to the movable jaw of the pneumatic-operated billet follower device.

Signals are picked up by the two wheel search units and fed into the reflectoscope unit, which evaluates the severity of the indication according to a preset level. Signals above a given level pass through a transigate monitor into an amplifier and are fed to a Brush pen recorder, where they cause a jog in the pen trace. The recorder is started and stopped as the billet enters and leaves the follower by microswitch controls. Signals are also recorded on separate traces which denote the interface and black reflection levels.

The combination of in-line mechanized magnetic particle and ultrasonic testing offers attractive possibilities for timely quality control of in-process material. This system would include storing process variable measurements in an off-line computer during billet production, magnetic particle testing, and ultrasonic testing of each billet, sorting the billets into quality level categories, combining the results of the surface and internal inspection with the prior processing data, and making process changes based on the computer analysis of this information.

\section{when you need}

LITERATURE SEARCHES

TRANSLATIONS

BOOKS ON LOAN

PHOTOPRINTS

why not contact ...

The Engineering Societies

345 East 47th Street New York 17, N. Y.

Please send me information pamphlet on services available, how air mail can expedite them, and their cost.

\section{Name}

\section{Street}

\section{City}

State
MICROFILM Library

American Air Filter Co. 1292

American Bridge Div./U. S. Steel Corp.

Bausch \& Lomb Inc. 1298

Bell Telephone Labs

Buehler, Ltd.

Cerium Metals \& Alloys Div.,

Ronson Metals Co.

Chicago/Wellsville Fire Brick Co.'s

1277

Concast 1304

Corhart Refractories Co. 1299

Dravo Corp.

Eastern Associated Coal Corp.

1291

Elektrokemisk A.S. 1300

Exomet, Incorporated 1302

Frankel Co. Inc. Cover IV

General Motors

1297

General Refractories Co.

1293,1301

Gordon \& Breach

1282

Great Lakes Carbon Corp.,

Graphite Products Div.

1305

A. P. Green Fire Brick Co.

Gutehoffnungshutte

1308

Harbison-Walker Refractories Co.

1288A-1288D

Hawley Fuel Corporation

1273

Kaiser Refractories Co.

1311,1312

Koppers Co.

Laboratory Equipment Corp.

1296

Lectromelt Furnace 1420-Cover III Arthur G. McKee \& Co.

Oglebay Norton Co.

1281

Pennsylvania Engineering Corp.

Perkin-Elmer Corp.

1303

Shawinigan Products Corp.

1295

Shenango, Inc.

1279

C. H. Sprague \& Son Co. 1309 PROFESSIONAL PERSONNEL SERVICE

\author{
29 E. Madison St.
}

Chicago, III. 60602

(312) ST 2-2748

\section{H. Wierschem, Proprietor}

(formerly manager Chicago office of E.S.P.S.)
Standard Lime and Refractories Co. .- 1287

Stora Kopparbergs Bergslags _..._..... 1306

Swindell-Dressler Corp.

The Chas. Taylor Sons Co.

Union Carbide Corp.

Carbon Products Div.

Union Carbide Corp.

Olefins Division

Unitron

Vanadium Corporation of America _..... 1296

Vulcan Mold and Iron Company _..... 1283

Walsh Refractories Corp. - 1316

Whiting Corp. _... 1288

Wilson Welding Co., Inc. ........ 1310 